\title{
An employer branding strategy: developing a talent atraction model through action research
}

\author{
DOI: $10.46932 / \mathrm{sfjdv2n1-031}$
}

Received in: November 1st, 2020

Accepted in: December 30th, 2020

\author{
Raquel Noutel \\ Grupo Salvador Caetano, Vila Nova de Gaia, Portugal \\ E-mail: raquelnoutelsantos@gmail.com \\ Patricia Araujo \\ ISMAT - Instituto Superior Manuel Teixeira Gomes, Portimão, Portugal \\ E-mail: pattaraujo@gmail.com \\ Rosina Fernandes \\ ESEV e CI\&DEI - Instituto Politécnico de Viseu, Portugal \\ E-mail: rosina@esev.ipv.pt \\ Paula Arriscado \\ IPAM - Instituto Português de Administração e Marketing, Porto, Portugal \\ Grupo Salvador Caetano, Vila Nova de Gaia, Portugal \\ E-mail: paulaarriscado@gmail.com
}

\begin{abstract}
Organizational difficulties in attracting talent should alert to the need of employer brands to present characteristics differentiating them from competitors. Employer branding is a fusion area between human resources and marketing, which aims to build an organization's reputation as a great place to work. The future of organizations depends on the quality of the workforce they can attract (Chhabra \& Sharma, 2014) and people, as brands, are the most important assets in a company (Backhaus \& Tikoo, 2004). This research aimed to conceive and test a talent attraction model of graduated engineers for a large business group with decades of experience in industry and automotive sectors, in Portugal. Action research was performed in two cycles, consisting in focus group, intervention (detailed organizational presentation) and a final survey with 6 questions about organizational attractiveness of the organization in study. The Employer Attractiveness Scale by Berthon, Ewing and Hah (2005) was used as a guiding paradigm. Twenty recent graduates and finalists participated, with an average age of 23, male, from Mechanical, Automotive Mechanical and Industrial Management Engineering degrees of two Oporto Schools (Portugal). Data was collected personally, by researchers on campus. NVivo Content analysis and descriptive statistics were used, and intervention improvements were introduced before the second cycle. Results showed that: (i) The most valued dimensions by participants were development and economic; (ii) Before the intervention, students didn't know the organization well, neither in terms of business areas or size; (iii) Post-intervention, participant's opinion about the organization improved, with an average of 6.4 (1-7 lickert scale); (iv) After the intervention 90\% would consider the organization as their employer. Based on the two cycles and organizational information, a model for engineer attraction was proposed, however, it's overall principles might be adapted and applied to other areas of talent and different organizations facing similar challenges.
\end{abstract}

Keywords: Employer Branding, Talent atraction, Enginnering, Action Research. 


\section{INTRODUCTION}

Organizations are considering new ways to build their brands, endowing them with attributes that classify them as employers and that differentiate them from competitors. Corporate investment in Employer Branding (EB) is a recent and relevant trend for organizations, since one of the biggest corporate challenges is the search and struggle for qualified talent (Chhabra \& Sharma, 2014; Wilden, Gudergan, \& Lings, 2010). To attract talent, organizations must become attractive to potential employees, by clearly defining their attributes, in comparison to their competitors, creating an Employee Value Proposition (EVP) - which encompasses everything they offer as employers, from the global level compensation, to the work environment. A new big challenge is the generational hodgepodge and the fact that they have to attract an increasing number of millennials, with job expectations quite different from other generations (Garibaldi, 2014). Following new approaches of merging Human Resources (HR) and Internal Marketing (IM) approaches (Araújo, Fernandes, Martins \& Mendes, In Press; Rafiq \& Ahmed, 2000) organizations will work with focus on capturing and developing strategic competencies for the satisfaction of the internal customer (costumer centric strategy). Attracting talent strategic vision aims to increase EB attractiveness through people management oriented to the needs of customers (Sousa, Arriscado \& Noutel, 2019). In this paper, we present a research that aimed to reinforce the EB of a Portuguese group, which has been feeling the constraints of recruiting and positioning as an employer and has had to review their people management guidelines and HR politic and practices. Action Research was used to investigate engineering students' perceptions about the group's employer brand, to increase positive opinions of potential workers (intervention) about the brand and, finally, to create a model for talent attraction for future HR and Internal marketing practices. The research presented in this paper was first presented to a Master Thesis research (Noutel, 2019).

\section{INTERNAL MARKETING, BRANDING AND EMPLOYER BRANDING}

\subsection{INTERNAL MARKETING (IM)}

IM is a recent and polysemic concept (Rafiq \& Ahmed, 2000) which may justify the fact that organizations are only now becoming aware of its importance and potential applications (RundleThiede, 2015). IM's goal is to treat employees as a group of customers (Kotler, 2000), the internal client. In this way, it is possible to have a workforce committed to the values and objectives established by the company (Backhaus \& Tikoo, 2004). It is a strategic process to create brand ambassadors within the organization, who represent it as the best place to work in the external market (Asha \& Jyothi, 2013). It is necessary for decision makers to understand the role that internal clients can play in external clients (customers) satisfaction, through their commitment and involvement with the organizational cause 
(Kelemen \& Papasolomou- Doukakis, 2004). Two perspectives have dominated Internal Marketing's thinking (Rundle- Thiede, 2015). Berry's (1981), who considers that employees should be treated as internal customers because they have, like external customers, desires and motivations that must be realized, and Grönroos' (1983), who believes that the orientation towards client must be achieved through influence, instead of satisfying and motivating employees, as suggested by Berry (1981). The dimensions most valued by Grönroos have an external orientation, while Berry's have an internal focus (RundleThiede, 2015). It was with the definition created by Leonard Berry, in 1981, that the term gained popularity. He affirmed that IM is about viewing employees as internal customers and viewing jobs as internal products (Rafiq \& Ahmed, 2002). The American Marketing Association (AMA) defines IM as Marketing for employees, which acts as a guarantee that they are effectively developing work that they enjoy doing. Organizations should consider IM in all their activities, from writing emails to disseminating corporate information (Kaplan, 2017). IM promotes the idea that no management function can't act alone and joint action should be taken between functions and departments, such as Marketing and HR, with the common point of view in satisfying the internal customer (Rafiq \& Ahmed, 2003).

\subsection{BRANDING}

Branding emerged as a management need in the 1990s, due to a growing perception that brands are one of the most valuable intangible assets that companies have (Keller \& Lehmann, 2006). Even today, brand management is one of the biggest challenges for a company (Rodriguez, Lopez, \& Lores, 2014). Keller (2013) points out that the first function of a brand is identification. However, he also clarifies that a brand is not a symbol or a logo, but something that, in addition to identify, adds other variations and creates awareness and promotion in the market (Keller, 2013). Kotler (1991) defined brand as a name, term, sign, symbol or design, or a combination of them, that identifies the goods or services of a seller or group of sellers and differentiate them from the competition. The American Marketing Association (2017) classify a brand as a name, term, design, symbol or any other resource that identifies the good or service of a seller. So, a brand is a sample of perceptions related to the attributes, benefits, functions and symbols of a brand, that exists in consumer's mind (Keller, 2013). The loyalty to a brand is a link that the customer has with it and that makes him less likely to think about changing one brand for another (Aaker, 1991). Consumption does not comprise brands only for their functional attributes, but also for their symbolic ones. For those who drive a brand, it matters to understand the meaning of the brand inside consumer's mind (Lievens \& Highhouse, 2003). The approach of employment to the reality of brands results from the demanding challenges in attracting and retaining talent, which makes essential to develop a communication strategy for recruitment (Elving, Westhoff, Meeusen and 
Schoonderbeek, 2013) and an inherent EB strategy, applying the principles of branding to employment (Sousa, Arriscado, Ferreira and Quesado, 2016).

\subsection{EMPLOYER BRANDING}

The concept of brand has evolved in terms of definition and scope, being initially confined to products and services and now extended to ideas, events, sites and employers (Kapoor, 2010). Jobs must now be managed in a similar way to a product, using marketing techniques to design job offers, so that the needs of potential employees and employers intersect (Wilden, Gudergan \& Lings, 2010). All organizations must be aware that they have an employer brand, whether they work it actively or not (Minchington \& Thorne, 2007). Currently, one of the biggest corporate challenges is the search and competition for the most qualified talent (Chhabra \& Sharma, 2014; Wilden et al., 2010) and human capital, alongside brands, constitutes one of the most important assets of a company (Backhaus \& Tikoo, 2004). Competitiveness in the labor market has made it imperative for organizations to create differentiation as employers, to stand out from the competition (Kapoor, 2010). It is from this need that the EB approach emerged in the 1990s by Ambler and Barrow (1996), who defined it as the package of functional, economic and psychological benefits, provided by employment and identified by companies. The original focus of the concept was to ensure clear and coherent thinking in defining a value proposition for employees, in the same way that it was done for consumer brands (Mosley, 2007). EB emerges as a new approach for organizations to differentiate themselves and gain competitive advantage (López, Tarodo \& Lores, 2014) and its function is to provide a coherent management framework, to simplify and focus on priorities, increase productivity, improve recruitment, retention and commitment (Ambler \& Barrow, 1996). The employer brand is the result of the application of several concepts of Marketing, especially Branding, and HR, to highlight a certain positioning of a company in its role as an employer. The intention of this Marketing process is similar to any other commercial brand: to attract new customers and keep the current ones. But attention should be paid not only to the issue of attraction, but also to retention, since it is more effective, cheaper and more efficient to keep the current ones, than to recruit new customers (Ambler \& Barrow, 1996). The complexity of an EB building process is due to the fact that it is not an end in itself.

"Employer's brand is about continuous Marketing, which does not end with the signing of a contract" and, therefore, sporadic attempts to work an employer brand are futile and without results (Kapoor, 2010, p.54). This construction results from a complex process, based on multiple contributions, such as brand awareness, its positive and negative attitudes, loyalty, trust and the feeling that the brand is there for the employee, when he needs it. For all these reasons, the employer brand is the one with 
which an employee establishes a close relationship (Ambler \& Barrow, 1996). As in all Marketing processes, building or installing perceptions about a brand is not an easy process. The employer's brand must therefore build a company identity as an employer, unique and identifiable, differentiated from competitors (Backhaus \& Tikoo, 2004). For an organization be able to transform itself in a benchmark employer, that goes beyond successful recruitment and retention, it must be supported by committed employees with the organization's mission, vision and values (Kapoor, 2010). These kinds of feelings will bring employees' loyalty to an employer brand. This loyalty depends on the transfer of employees from an employment contract to a psychological contract (Chhabra \& Sharma, 2014). This relationship that is built between the organization and the employee translates into several exchanges of mutual benefits. The employer brand provides the employee with useful personal and professional development activities - functional scope - monetary or material rewards - economic scope - and the feeling of belonging to a certain organization - psychological scope (Ambler \& Barrow, 1996). Indeed, for Bakhaus and Tikoo (2004) the elements that constitute an employer brand are: the functional and the symbolic benefits. Functional benefits are those elements of the job itself, which are desirable in objective terms, such as salary or flexible benefits. As for the symbolic ones, they are related to perceptions about the company, such as the prestige or the social approval that a candidate feels when entering a certain organization. In a recruitment context, potential candidates will be attracted to an organization based on beliefs about desired attributes and not just functional benefits, which are not enough to provide a first attraction to a particular company (Backhaus \& Tikoo, 2004; Lievens \& Highhouse, 2003). If the potential employee has insufficient and inconsistente information or wrong beliefs about the potential employer, he can perceive high risks regarding the integration in the organization and, consequently, remove it from the range of employer options and choose another one, of which he has more and better information and therefore perceive less risk. Thus, the sharing of clear and consistent communication signals must be included in the employers' investments, so that they can guarantee a place at the top of the thoughts of potential employees (Wilden et al., 2010). In this process, employees have a decisive role in the successful construction of the employer brand, and their behavior may reinforce the brand values or, on the other hand, make the job messages conveyed fragile (Berthon et al., 2005).

\section{METHODS}

A Case Study of a Portuguese industrial group was implemented (Yin, 2013) and Action Research (AR) was the elected methodology. This AR aims to develop a talent attraction model, specifically conceived and tested for a company within the field of Engineering. AR is a designation first time used by Kurt Lewin, in 1946 (Saunders, Lewis \& Thurnhill, 2009) and it's a methodology that 
allows studying the resolution of a practical organizational problem and possible to investigate, involving those living situation (participative perspective), through a cyclical sequence of events, that intend to reach a solution for given problem, resulting in both learning and contributions to scientific knowledge (Coughlan \& Coghlan, 2002). Specifics goals are: (a) Identify most valued employer attractiveness scale (EmpAt) (Berthon et al., 2005) dimensions by the participants; (b) Determine students' perceptions of the organization as an employer; (c) Measure the impact of the action taken in the action-research cycles.

\subsection{PARTICIPANTS}

Participants were students, finalists or recent graduates, in the field of Engineering (a core area for the organization), from two colleges in Porto. Twenty male students participated, mainly finalists or recent graduates of the Mechanics and Industrial Management courses (Table 1).

Table 1: Characterization of participants

\begin{tabular}{|c|c|c|c|c|c|c|c|c|}
\hline AR cycle & $\begin{array}{l}\text { Nun } \\
\text { part }\end{array}$ & $\begin{array}{l}\text { rof } \\
\text { ants }\end{array}$ & Degree/ Course & $\begin{array}{l}\text { Situation } \\
\text { (in relation to } \\
\text { the course) }\end{array}$ & $\begin{array}{c}\text { Age } \\
\text { (Mean) }\end{array}$ & Min. Age & $\begin{array}{c}\text { Max. } \\
\text { Age }\end{array}$ & Gender \\
\hline \multirow{3}{*}{$\begin{array}{l}\text { First } \\
\text { cycle }\end{array}$} & \multirow{3}{*}{10} & 5 & Mechanical Engineering & 2nd year & \multirow{3}{*}{21.8} & \multirow{3}{*}{19} & \multirow{3}{*}{22} & \multirow{6}{*}{ Male } \\
\hline & & 2 & $\begin{array}{c}\text { Automotive Mechanical } \\
\text { Engineering }\end{array}$ & $\begin{array}{c}\text { Recent } \\
\text { graduates }\end{array}$ & & & & \\
\hline & & 3 & & Finalists & & & & \\
\hline \multirow[t]{2}{*}{$\begin{array}{l}\text { Second } \\
\text { cycle }\end{array}$} & \multirow[t]{2}{*}{10} & 2 & $\begin{array}{l}\text { Industrial Management } \\
\text { Engineering }\end{array}$ & $\begin{array}{l}\text { Recent } \\
\text { graduates }\end{array}$ & \multirow[t]{2}{*}{24.4} & \multirow[t]{2}{*}{21} & \multirow[t]{2}{*}{26} & \\
\hline & & 8 & Mechanical Engineering & Finalists & & & & \\
\hline TOTAL & \multicolumn{2}{|c|}{20} & - & - & 23.1 & - & - & \\
\hline
\end{tabular}

\subsection{DATA COLLECTION}

All our AR approach was based on the Employer Attractiveness Scale (EmpAT) dimensions and items (Berthon et al., 2015), which assesses employer attractiveness through 5 dimensions and 25 items: (a) interest dimension, related to the innovation practices and products quality and services; (b) social dimension, about the work environment and the relationship with colleagues and supervisors; (c) economic dimension, related with the salary, compensation plan and opportunities within the organization; (d) development dimension, includes feelings such as self-confidence and happiness derived from working for a specific organization; (e) application dimension, related with social responsibility and customer-orientation. 


\subsubsection{Focus Group}

Two focus groups were held, both with 10 students, from various courses and years of schooling, as shown in Table 1. The guidelines were built in two parts: first part with two introductory questions (What are the main factors that motivate you in choosing an employer? and My ideal employer...) and the second part, based on the dimensions of the EmpAt scale and with suggestive images of each one, to spark the discussion.

\subsubsection{Questionnaire survey}

The survey consisted in 6 questions, divided in 2 groups. The first group had two questions about the participants' knowledge of the organization before the session, and a last third one about their opinion after the session, through a scale of 1 to 7 , in which 1 means nothing interesting and 7 means totally interesting: (a) Did you know the organization before participanting in this session?; (b) Were you aware of its dimension?; (c) To what extent, now, after the session, would you like to have an organization as your employer?. The second group intended to evaluate the potential of the organization as an employer, through the evaluation of each dimension, also on the same scale of 1 to 7 . The objective was to obtain the average evaluation of each dimension. The questions were: (a) Now, thinking about the organization as your potential employer, give us your opinion about how you feel about each of the dimensions; (b) Which dimension is most attractive to you?. The last question was: (a) How did your opinion of the organization as an employer change for better after the session?. Sociodemographic data, age, professional experience and situation regarding the course (recent graduate, finalist or other), were requested.

\subsection{PROCEDURE}

This research was developed within a Master thesis (Noutel, 2019) and was carried out with the supervision of the company and the thesis supervisor from IPAM (Portuguese Institute of Administration and Marketing).

The universities selection and the field of study - Engineering - was made considering the company's difficulties in talent attraction. This was possible thanks to the help of academic services and student associations, which also helped in choosing dates according to school hours, so as not to disturb and achieve the greatest possible adhesion. The first cycle of investigation took place on May 22, 2019 and the second on June 4, 2019. Both had an approximate duration of 1 hour and 15 minutes. Both sessions started with the focus group, led by the researcher, followed by the presentation of the company (corresponding to the action of the research-action cycle), made by an element of the organization's Human Resources, which consisted of the presentation of the organization, of its various business areas 
and respective companies. Lastly, the questionnaire was applied. There were difficulties contacting with colleges. In the first cycle, contact was made through academic services, which helped communicating with the students and provided the material for the session (room and projector). In the second cycle, although the contact was initially with academic services, we ended up organizing the sessions through the students' association, with whom contact was easier, and who provided all the material for the session (room and projector) and helped communicate with students. Overall, students were cooperative: Focus-group and company's presentation lasted 30 minutes each and the survey took about 5 minutes.

\subsection{TRUSTWORTHINESS: VALIDITY TECHNIQUES IN QUALITATIVE RESEARCH}

Since direct contact between the researcher and the studied situation is implicit (Ceballos, 1998) and qualitative techniques were used, reflections on trustworthiness must be made following recommendations by Whitmore, Chase and Mandle (2001), and so, several trustworthiness measures were applied: (a) research design according to objectives; (b) choice of a non- probabilistic sample for convenience, validated by the organization; (c) triangulation with colleagues (four master students) and thesis supervisor, on all decisions throughout the research; (d) pre-test of material: this pre-test was also implemented in a supervised session with four marketing management master students which attended the simulated presentation, and then debated difficulties in understanding the content, design, power point exactness and logic; (e) temporal and space triangulation, since data collection was in different places, universities and time-frame; (f) full transcript of focus group sessions; (g) use of NVivo software to help in qualitative analysis; (h) use of quotes from participants to support evidence taken from the investigation process.

\subsection{DATA ANALYSIS}

CAQDAS (Computer Assisted Qualitative Data Analysis) was used, through NVIVO software to analyze the data obtained in the focus group sessions. Descriptive analysis of the data collected in the questionnaire survey was performed using Excel.

\section{RESULTS}

\subsection{FIRST ACTION-RESEARCH CYCLE}

The responses of the participants were analyzed considering the dimensions of the Empat scale.

The most mentioned words in this cycle were (a) career $(n=10)$; (b) dimension $(n=8)$ and (c) training $(n=6)$. They correspond to the development dimension $(n=36)$, considered the most important in 
this cycle. These words were analyzed separately to understand the context. The word career was associated with the desire to have a better understanding of career possibilities, plans and functions in the organization. Training was associated with the desire for constant learning, provided by an employer with training and skills development programs. The second dimension considered most important was the economic dimension, with a frequency of 12 . They say it is a decisive dimension in choosing an employer and the importance of flexible benefits was unanimous.

As for the other dimensions, the participants considered the social dimension to be important, namely the relationship with the boss, but, in general, they do not consider it fundamental to the choice of an employer. The application dimension was also not considered essential, although they do not neglect the importance of Social Responsibility initiatives. The interest dimension was considered very relevant, especially regarding the innovation of products and services. Ninety percent revealed to know the organization before the session, but only twenty percent had idea of its size. After the session, the majority (8) of students would like to have the organization as an employer, having selected options 6 or 7, on a scale of 1 to 7 . Regarding the opinion about the organization and if it changed for better after the session, the average was

4.8 , on a scale of 1 to 7 . Considering the same scale, the best rated dimension was the economic one (6.2), followed by development (6.1), interest and application (5.9) and, finally, social (5.4).

\subsection{IMPROVEMENTS INTRODUCED}

After researchers triangulation, improvements were introduced for the second cycle: (a) reduction of the organization's indicators, such as number of employees, sold units, etc.; (b) introduction of a new section about industrial components and innovation processes and developments; (c) more information about the trainees' program; (d) video testimonials by former trainees that stayed in the company after internships and others with consolidated careers in the organization. All improvements are supported by the first cycle participants: (a) disclosure of innovation processes; (b) I would like to know more about the functions performed in each company, mainly in the industry; (c) be close to the colleges, planning visits to the facilities, proposals for summer internships and themes for Master's theses; (d) greater relationship with young graduates, through the internship program; (e) greater clarification regarding the functions or positions that a future Automotive Mechanic Engineer can perform in the Group and career prospects. 


\subsection{SECOND ACTION-RESEARCH CYCLE}

The most mentioned words in this focus group were remuneration $(n=10)$, dimension $(n=6)$ and environment $(n=5)$. These references correspond, respectively, to the economic dimension (19 references) that was considered the most important in this cycle, development dimension (19 references) and social dimension (14 references). Remuneration was considered very relevant because it is the visible part of an organization and, therefore, relevant in the choice, due to the little knowledge that one has of other aspects before arriving at a company. They highlighted the compensation plan as crucial for attracting and retaining candidates. The dimension of an employer was mentioned because it is considered a good attribute for choosing a large and recognized company, instead of a smaller one. The work environment was considered important, particularly in the relationship with the boss and the autonomy that may result from it. About the application dimension, aspects such as Social Responsibility were not considered essential, since, according to the participants, these aspects do not affect the work and they would consider working in a place without this type of practices. As for the interest dimension, they consider innovation very important, since they intend in their work to develop solutions to practical problems. Ninety percent of participants said they already knew the organization before this session and $20 \%$ were aware of its size. After the session, most students would like to have the organization as an employer, having selected options 6 or 7 on a scale of 1 to 7 . Regarding the opinion about the organization and if it changed for the better after the session, the average was 6.4. The evaluation of the organization by dimensions had the economic dimension as best classified (6.5), followed by the development (6), interest (5.7), application (5) and, finally, the social dimension (4.5).The organization's overall rating went from 4.8 to 6.4 .

We can therefore consider that the changes - which consisted in more information about the industrial component of the organization - had a positive impact on the action, having increased the employability attractiveness of this Portuguese group.

\subsection{TALENT ATTRACTION MODEL}

This research main objective was the creation of a model (Figure 1) for the organization to become more attractive as an employer. 
Figure 1: Final Design of the Talent attraction model for a Portuguese Industrial Group

\section{Plan}

Think about the potential employees and how the company plans to reach their attention

Design the Intervention strategically

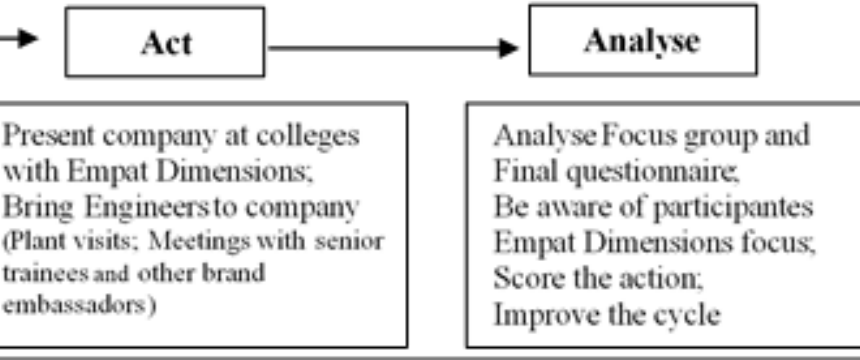

Repeat and improve the cycle | Focus on improving Employer actractiveness | Adapting content to audiences | Update company's evolutions | Use model for internal Marketing and talent retention | Engage Marketing and Human resources

This model was effective and improved participants opinion and therefore, positively impacted the organization's employer brand. At the end of the cycles, most participants would like to have the company as their employer (Noutel, 2019).

\section{CONCLUSIONS AND DISCUSSION}

After this investigation process, we can conclude that the model works: (a) students were surprised and impressed by the size of the organization and the variety of businesses; (b) they improved their opinion about the organization as an employer; (c) most of them would not mind having the organization as an employer; (d) the intervention by researchers changed the participants opoiniao about the company for the best. In addition to this, we also became more aware of the dimensions that they value most and the aspects that we should improve. In general, we can say that the amount of information they have about a company is directly proportional to the desire to work there, since the unknown does not attract potential candidates. Therefore, the integration of HR strategies and processes with communication and marketing plans is very important. This model can be implemented and improved in the future, in several areas of the organization. The process of building an Employer Brand must be articulated and consistent with the corporate brand and the product brands of an organization (Ambler \& Barrow, 1996; Backhaus \& Tikoo, 2004). It is due to its relevance that it should not be left solely to marketeers or HR managers. This integration must consider Marketing, Communication and Human Resources, whose actions will impact the organization's branding objectives (Ambler \& Barrow, 1996; Kapoor, 2010; Wilden et al., 2010). In fact, during the two Action-Research cycles we could hear student's voices asking a better disclosure of the trainees programme because most of them affirmed that only knew its existence in that day. They also agreed that job fairs model is outdated because does not allow students to talk properly with company's staff as much as they want to, in order to know better about specific functions of other Engineers in the company. In fact, this construction can only be successful when organizations understand all the factors that contribute to the attractiveness of the 
employer, namely those to which this investigation led us. Disclosure of career plans, knowledge of the company through social media and another events beyond job fairs that could put them in contact with employees are the major suggestions made by the participants.

Even though this study was conducted based on a specific organization, with a specific geographical location and using a specific area of talents' attraction and retention, it should be able to draw attention to the need for organizations to make their more robust employer brands, bringing marketing and communication knowledge and techniques to the HR area. The organization can test this model in the future with other engineering students or even in other areas where they feel the constrains about talent attraction. The organization can also try a better content analysis, to understand students' opinions and their suggestions. The action of researchers in social sciences must be in the sense of giving more and more prominence to EB, validating it as a useful premise in HR management (Backhaus \& Tikoo, 2004). Further investigations should be conducted to help organizations successfully implement their EB, based on valid criteria, with appropriate tools and techniques. Actually, the possibility that, in the future, competition for the best employees will be as significant as the competition for customers should reflect for this theme's urgency (Berthon et al., 2005). 


\section{LITERATURE}

1. Aaker, D. A. (1991). Managing brand equity: capitalizing on the value of a brand name. Marketing Research (1st ed.). New York: The Free Press.

2. American Marketing Association. (2017). Dictionary - AMA. Retrieved December 17, 2018, from: https://www.ama.org/resources/pages/dictionary.aspx?dLetter=B

3. Ambler, T., \& Barrow, S. (1996). The employer brand. Journal of Brand Management, 4(3), 185-206. https://doi.org/10.1057/bm.1996.42

4. Araújo, P. Fernandes, R., Martins, E. \& Mendes, F. (In Press). The emergence of Human Resources Marketing framework: How Internal Marketing approach is changing organizational happiness interventions. WORK: Journal of Prevention, Assessment \& Rehabilitation

5. Asha, S. \& Jyothi, P. (2013). Internal Branding: A Determining Element of Organizational Citizenship Behaviour. Contemporary Management Research, 7(1), 37-57

6. Backhaus, K., \& Tikoo, S. (2004). Conceptualizing and researching employer branding. Career Development International, 9(5), 501-517. https://doi.org/10.1108/13620430410550754

7. Berry, L. L. (1981). The Employee as Customer. Journal of Retail Banking, 3, 25-28.

8. Berthon, P., Ewing, M., \& Hah, L. L. (2005). Captivating company: dimensions of attractiveness in employer branding. International Journal of Advertising, 24(2), 151-172. ttps://doi.org/10.1080/02650487.2005.110729129. Ceballos, P. (1998). Un Método para InvestigaciónAcción Participativa. $3^{\text {rd }}$ Ed. Madrid: Ed.Popular

10. Chhabra, N. L., \& Sharma, S. (2014). Employer branding: Strategy for improving employer attractiveness. International Journal of Organizational Analysis, 22(1), 48-60. https://doi.org/10.1108/IJOA-09-2011-0513

11. Coughlan, P., \& Coghlan, D. (2002). Action Research: action research for operations management. International Journal of Operations \& Production Management, 22 (2), 220-240.

12. Coutinho, C. P. (2014). Metodologia de Investigação em Ciências Sociais e Humanas: teoria e prática. Coimbra: Almedina.

13. Elving, W. J. L., Westhoff, J. J. C., Meeusen, K., \& Schoonderbeek, J. W. (2013). The war for talent the relevance of employer branding in job advertisements for becoming an employer of choice. Journal of Brand Management, 20(5), 355-373. https://doi.org/10.1057/bm.2012.21

14. Garibaldi, A. (2014). Employer Branding for Dummies, Glassdoor Special Edition. New Jersey: John Wiley \& Sons.

15. Grönroos, C. (1983). Service Marketing: Theory and Practice. Cambridge: Marketing Sci. Institute. 
16. Kaplan, R. (2017). Internal Marketing and Internal Branding in the 21st Century Organization. Journal of Brand Management. Vol. 14(2), 7-22.

17. Kapoor, V. (2010). Employer Branding: A Study of Its Relevance in India. Journal of Brand Management, 7(1/2), 51-75. http://doi.org/10.1006/bbrc.1995.2566

18. Kelemen, M., \& Papasolomou-Doukakis, I. (2004). The Service Industries Can culture be changed? a study of internal marketing, The Service Industries Journal, 24(5), 121-135. doi: http://10.1080/0264206042000276874

19. Keller, K. L. (2013). Conceptualizing, Measuring, and Managing Customer-Based Brand Equity. Journal of Marketing, 57 (1), 1-22.

20. Keller, K. L., \& Lehamn, D. R. (2006). Brands and Branding: Research Findings and Future Priorities. Marketing Science, 25 (6), 740-759.

21. Kotler, P. (1991) Marketing Management. 7th Edition, Prentice-Hall, Englewood Cliffs

22. Kotler, P. (2000). Marketing Management. New Jersey: Prentice Hall.

23. Lievens, F., \& Highhouse, S. (2003). The relation of instrumental and symbolic attributes to a company's attractive- ness as an employer. Personnel Psychology, 56(1), 75-102.

24. López, F., Tarodo, A., \& Lores, S. (2014). Branding: estudio multinacional sobre la construcción de la marca del empleador. UNIVERSIA Business Review, 20(44), 34-53.

25. Minchington, B., \& Thorne, K. (2007). Measuring the effectiveness of your employer brand. Human Resources Institute of New Zealand, Human Resources Magazine, 12(4), 14-16.

26. Mosley, R. W. (2007). Customer experience, organisational culture and the employer brand. Journal of Brand Management, 15(2), 123-134.

27. Noutel, R. (2019). A marca empregadora Salvador Caetano: desenvolvimento de um modelo para a atração de talento [Salvador Caetano's Employer Brand: Developing A Talent Atraction Model]. Master's Dissertation supervised by $\mathrm{PhD}$ Patrícia Araújo. Oporto: IPAM- Portuguese institute of Administration and Marketing.

28. Rafiq, M., \& Ahmed, P. K. (2000). Advances in the internal marketing concept: definition, synthesis and extension. Journal of Services Marketing. https://doi.org/10.1108/08876040010347589

29. Rafiq, M., \& Ahmed, P. K. (2002). Internal Marketing: tools and concepts for customer-focused management. Elsevier.

30. Rundle-Thiele, Y. T. (2015). A holistic management tool for measuring internal marketing activities. Journal of Services Marketing, 29 (6/7)

31. Saunders, M., Lewis, P. \& Thornhill, A. (2012). Research methods for business students. Essex: Pearson Education. 
32. Sousa, B., Arriscado, P., Ferreira, P., \& Quesado, H. (2016). The role of employer branding on attracting, developing and retaining talent: the case of a leading Portuguese business group. Revista Portuguesa de Marketing, 19(36), 23-42.

33. Sousa, B., Arriscado, P., \& Noutel, R. (2019). Employer Branding: o Portal Arte. In Gestão e Desenvolvimento de Recursos Humanos (111-122). Porto: Vida Económica.

34. Teddlie, C., \& Tashakkori, A. (2009). Foundations of Mixed Methods Research: integrating quantitative and qualitative approaches in the social and behavioral sciences. London: Sage.

35. Wilden, R., Gudergan, S., \& Lings, I. (2010). Employer branding: Strategic implications for staff recruitment. Journal of Marketing Management, 26(1-2), 56-73. https://doi.org/10.1080/02672570903577091

36. Whittemore, R., Chase, S. K., \& Mandle, C. L. (2001). Pearls, Pith, and Provocation: Validity in qualitative research. Qualitative Health Research, 11(4), 522-537.

37. Yin, R. (2013). Case Study Research: Design and Methods. Sage Publications. 